OPEN ACCESS

Edited by:

Maria Florencia Quiroga, Universidad de Buenos Aires,

Argentina

Reviewed by:

Jason Scott Stumhofer, University of Arkansas for Medical Sciences, United States

Shahram Salek-Ardakani, Pfizer, United States

*Correspondence: Satish Devadas satdevs@ils.res.in

Specialty section: This article was submitted to T Cell Biology, a section of the journal Frontiers in Immunology

Received: 18 January 2018 Accepted: 26 April 2018 Published: 28 May 2018

Citation:

Jogdand GM, Sengupta S, Bhattacharya G, Singh SK, Barik PK and Devadas S (2018) Inducible Costimulator Expressing T Cells Promote Parasitic Growth During

Blood Stage Plasmodium berghei ANKA Infection.

Front. Immunol. 9:1041 doi: 10.3389/fimmu.2018.01041

\section{Inducible Costimulator Expressing T Cells Promote Parasitic Growth During Blood Stage Plasmodium berghei ANKA Infection}

\author{
Gajendra M. Jogdand, Soumya Sengupta, Gargee Bhattacharya, Santosh Kumar Singh, \\ Prakash Kumar Barik and Satish Devadas*
}

Infectious Disease Biology, Institute of Life Sciences, Bhubaneswar, India

The lethality of blood stage Plasmodium berghei ANKA (PbA) infection is associated with the expression of T-bet and production of cytokine IFN- $\gamma$. Expression of inducible costimulator (ICOS) and its downstream signaling has been shown to play a critical role in the T-bet expression and IFN- $\gamma$ production. Although earlier studies have examined the role of ICOS in the control of acute blood-stage infection of Plasmodium chabaudi chabaudi AS (a non-lethal model of malaria infection), its significance in the lethal bloodstage of $\mathrm{PbA}$ infection remains unclear. Thus, to address the seminal role of ICOS in lethal blood-stage of $\mathrm{PbA}$ infection, we treated PbA-infected mice with anti-ICOS antibody and observed that these mice survived longer than their infected counterparts with significantly lower parasitemia. Anti-ICOS treatment notably depleted ICOS expressing CD4+ and $\mathrm{CD} 8^{+} \mathrm{T}$ cells with a concurrent reduction in plasma IFN- $\gamma$, which strongly indicated that ICOS expressing $T$ cells are major IFN- $\gamma$ producers. Interestingly, we observed that while ICOS expressing $\mathrm{CD}^{+}$and $\mathrm{CD}^{+} \mathrm{T}$ cells produced IFN- $\gamma$, ICOS ${ }^{-} \mathrm{CD} 8^{+} \mathrm{T}$ cells were also found to be producers of IFN- $\gamma$. However, we report that ICOS ${ }^{+} \mathrm{CD} 8^{+} \mathrm{T}$ cells were higher producers of IFN- $\gamma$ than ICOS-CD8 ${ }^{+} \mathrm{T}$ cells. Moreover, correlation of ICOS expression with IFN- $\gamma$ production in ICOS ${ }^{+} \mathrm{IFN}-\gamma^{+} \mathrm{T}$ cell population (CD4 ${ }^{+}$and $\mathrm{CD}^{+} \mathrm{T}$ cells) suggested that ICOS and IFN- $\gamma$ could positively regulate each other. Further, master transcription factor T-bet importantly involved in regulating IFN- $\gamma$ production was also found to be expressed by ICOS expressing $\mathrm{CD}^{+}$and $\mathrm{CD} 8^{+} \mathrm{T}$ cells during PbA infection. As noted above with IFN- $\gamma$ and ICOS, a positive correlation of expression of ICOS with the transcription factor T-bet suggested that both of them could regulate each other. Taken together, our results depicted the importance of ICOS expressing CD4 ${ }^{+}$and $\mathrm{CD} 8^{+} \mathrm{T}$ cells in malaria parasite growth and lethality through IFN- $\gamma$ production and T-bet expression.

Keywords: malaria, inducible costimulator, T cells, IFN- $\gamma$, T-bet, CD4, CD8

\section{INTRODUCTION}

Malaria is a major cause of mortality in millions of infected individuals every year, especially children from developing countries. Among all human Plasmodium strains, infection with Plasmodium falciparum is the leading cause of death involving severity, cerebral manifestation, and multi-organ dysfunction. To some extent, murine infection of Plasmodium berghei ANKA $(\mathrm{PbA})$ can be correlated 
to human $P$. falciparum infection corresponding to parasite growth, lethality, or severity and immune response (1). As human malaria studies are restricted to only clinical observations, modulation of $\mathrm{T}$ cell immune response in murine models can provide a better insight to ameliorate malaria pathology and vaccine design $(2,3)$. The role of T cells in malaria infection, however, has been controversial as studies have shown both its critical role in protection from the malaria parasite and its direct role exacerbating malaria pathogenesis. As an example, $\mathrm{CD}^{+} \mathrm{T}$ cells play a major role in the clearance of parasite Plasmodium chabaudi chabaudi blood stage infection (4). However, during lethal $\mathrm{PbA}$ infection, both $\mathrm{CD}^{+}$and $\mathrm{CD}^{+} \mathrm{T}$ cells are involved in cerebral manifestation. Moreover, depletion of both the $\mathrm{T}$ cells by antibodies before or during infection ameliorated pathology (5). Thus, these studies among others suggested that $\mathrm{T}$ cells play both protective as well as pathological roles during malaria infection.

In both human and murine malaria, $\mathrm{CD}^{+}$and $\mathrm{CD}^{+} \mathrm{T}$ cells are producers of IFN- $\gamma$, which have been shown to play crucial protective and pathological roles $(6,7)$. During lethal malaria infection, extraneous administration of IFN- $\gamma$ led to the dosedependent protection of BALB/c mice (8). In contrast, another study suggested that IFN- $\gamma$ produced by $\mathrm{CD} 4^{+} \mathrm{T}$ cells enhanced $\mathrm{CD}^{+} \mathrm{T}$ cell accumulation in the brain leading to augmented cerebral malaria (9). Moreover, suppressing IFN- $\gamma$ production from T-bet positive CD4 ${ }^{+} \mathrm{T}$ cells efficiently hampered parasite clearance (10). Also, studies with T-bet knockout mice have demonstrated the role of T-bet in regulating parasite burden as well as its role in pathogenesis during experimental cerebral malaria (11). Taken together, these studies indicated that both IFN- $\gamma$ and T-bet play a role in malaria parasite growth and lethality.

Along with antigenic stimulation, signaling through CD28 plays a critical role in T cell-mediated immunity in clearance of acute blood-stage $P$. chabaudi infection (12). Inhibiting CD28 signaling by blocking CD86 with anti-CD86 antibody preferentially differentiated T cells toward IFN- $\gamma$ producing Th1 cells and inhibited the Th2 cytokine IL-4. This Th1 cytokine IFN- $\gamma$ controlled acute parasite infection but did not play a role in limiting chronic malaria infection. Thus, blockade of CD28 signaling suggested that IL-4 production during malaria infection required CD28 signaling whereas augmentation of IFN- $\gamma$ illustrated the involvement of other co-stimulatory molecules (13). Moreover, P. chabaudi infection in the CD28 knock out mice also demonstrated that redundant CD28 signaling pathway with other costimulatory molecules might play a role in IFN- $\gamma$ production (14). Thus, these studies suggested that IFN- $\gamma$ production during malarial infection could involve other co-stimulatory molecules.

Inducible costimulator (ICOS), a CD28 homolog, plays a critical role in $\mathrm{T}$ cell proliferation, differentiation, cytokine secretion, cell-cell interaction, and B cell maturation (15-21). Depending on the nature of antigen and chronicity of infection, ICOS signaling mediates differential effector $\mathrm{CD}^{+} \mathrm{T}$ cell response. As an example, during Schistosome mansoni infection, Th2 and Tfh response were observed whereas, during Toxoplasma gondii and Mycobacterium tuberculosis infection (Mtb), it was a Th1 response (22-24). In contrast, during non-lethal blood stage P. chabaudi chabaudi infection, in the absence of ICOS, enhanced Th1 response led to reduced peak parasitemia (20). In case of CD8 ${ }^{+} \mathrm{T}$ cells,
ICOS signaling played a role in its activation, expansion, and enhanced secondary response $(21,25)$. A substantial defect in antigen-specific $\mathrm{CD}^{+} \mathrm{T}$ cells along with hampered $\mathrm{CD} 4^{+} \mathrm{T}$ cells response was observed during Salmonella infection in ICOS knockout mice (26). Moreover, during late stage of Mtb, ICOS deficiency was associated with reduced Mtb-specific $\mathrm{CD}^{+} \mathrm{T}$ cell response (27). Taken together, these studies strongly suggest that ICOS plays a critical role in $\mathrm{CD}^{+}$and $\mathrm{CD}^{+} \mathrm{T}$ cell response in both intra and extracellular infection. However, during lethal intracellular blood-stage of $\mathrm{PbA}$ infection, the role of ICOS in $\mathrm{T}$ cell response $\left(\mathrm{CD} 4^{+}\right.$and $\left.\mathrm{CD} 8^{+}\right)$remains unclear.

In this study, we examined the role of ICOS in parasite growth and lethality during lethal $\mathrm{PbA}$ infection in $\mathrm{BALB} / \mathrm{c}$ mice. We characterized ICOS expression and found that both $\mathrm{CD}^{+}$and $\mathrm{CD}^{+} \mathrm{T}$ cells express higher ICOS in the PbA-infected mice. Upon depletion of ICOS-expressing $\mathrm{T}$ cells by anti-ICOS antibody treatment, we observed prolonged survival of mice with lower parasitemia, suggesting a positive role for ICOS expressing T cells in $\mathrm{PbA}$ parasite growth. Further, we report that these $\mathrm{T}$ cells are major producers of IFN- $\gamma$ as correlated with reduced plasma IFN- $\gamma$ cytokine level and depleted percentage of ICOS expressing $\mathrm{T}$ cells upon anti-ICOS treatment. We found both $\mathrm{CD}^{+}$and $\mathrm{CD}^{+} \mathrm{T}$ cells expressed transcription factor, T-bet, which is already known to be involved in malaria pathogenesis. Collectively, our study demonstrates that ICOS expressing CD $4^{+}$and $\mathrm{CD} 8^{+} \mathrm{T}$ cells are involved in malarial parasite growth and lethality through IFN- $\gamma$ production and T-bet expression.

\section{MATERIALS AND METHODS}

\section{Ethics Statement}

The use of animals and animal procedures were approved by the Institutional Animal Ethics Committee, Institute of Life Sciences, Bhubaneswar, India in accordance with the "Committee for the Purpose of Control and Supervision of Experiments on Animals (CPCSEA).”

\section{Mice, Antibodies, Kits, Reagents, and Malaria Parasite}

Male BALB/c mice (6-8 weeks old) used for this study were maintained under pathogen-free condition at institutional animal house facility. Anti-mouse antibodies Alexa Fluor 700-CD8 (Clone 53-6.7), APC-cy7-CD19 (Clone 1D3), APC-cy7-CD45R/B220 (Clone RA3-6B2), were procured from BD Biosciences (San Jose, CA, USA), FITC-CD4 (clone GK 1.5), FITC CD278 (7E.17G9), APC-CD278 (Clone-C398.4A), PerCP-Cy 5.5-CD4 (clone RM4-5), PE-Cy7-IFN- $\gamma$ (clone XMG 1.2), PE-T-bet (clone eBio 4B10), Alexa Fluor 700-CD8 (53-6.7) were from eBioscience (San Diego, CA, USA), Brilliant violet 605 TCR Vb (clone H57-597), APC-CD278 (clone C398.4A), Anti-CD49b (clone DX5) were from BioLegend (San Diego, CA, USA). Purified antibodies Antimouse CD278 ICOS (clone 7E.17G9), Anti-Rat IgG2b isotype control, and anti-CD16/32 were procured from BioXcell (West Lebanon, USA). Dynabeads untouched mouse CD4 ${ }^{+} \mathrm{T}$ cell isolation kit was procured from Life Technologies AS (Oslo, Norway) and $\mathrm{CD}^{+} \mathrm{T}$ cell negative selection kit was from Stem cell 
technologies (Vancouver, BC, Canada). Phorbol 12-myristate 13-acetate (PMA), Ionomycin, Brefeldin A was procured from Sigma-Aldrich (St. Louis, MO, USA). Malarial parasite P. berghei ANKA (MRA-671, MR4, ATCC, Manassas, VA, USA) was obtained from MR4 repository, ATCC, Manassas, VA, USA.

\section{Parasite Infection}

Plasmodium berghei ANKA parasitized red blood cells were stored in liquid nitrogen. The parasitic infection was initiated by thawing $P$. berghei ANKA parasite stabilate and intraperitoneally (i.p.) injecting into a donor mouse. After initial expansion of parasites in the donor mouse, blood was collected from tail vein bleed and serially diluted in PBS. Infection was then induced in experimental mice by intravenous (i.v.) injection of $1 \times 10^{4}$ P. berghei ANKA parasitic RBCs. After 3 days of infection, percent parasitemia was enumerated by thin blood films stained with modified Giemsa stain (Sigma-Aldrich, St. Louis, MO, USA).

\section{In Vivo Depletion of ICOS-Positive T Cells}

On day 1 of $\mathrm{PbA}$ infection, ICOS positive T cells were depleted by administering a single dose of anti-CD278 monoclonal antibody (clone 7E.17G9) and its isotype control (rat IgG2b) at $0.2 \mathrm{mg}$ dose, via intraperitoneal (i.p.) injection in $200 \mu$ DPBS. Specific depletion of ICOS positive T cells was analyzed by flow cytometry as shown in figure (Figure $\mathbf{3 H}$ ).

\section{Determination of Plasma Cytokines}

On day 3 , day 5 , and day 7 , day of $\mathrm{PbA}$ infection, murine blood was collected in $15 \%$ acid citrate dextrose anticoagulant and centrifuged at $1,000 \mathrm{~g}$ for $10 \mathrm{~min}$. The collected plasma was stored in $-80^{\circ} \mathrm{C}$ until assayed for cytokines. Cytokine from stored plasma was quantified using the Milliplex mag mouse cytokine/ chemokine kit as per the manufacturer's protocol (Millipore, Billerica, MA, USA). The samples were acquired in Bio-plex200 system, and the concentration of cytokines was calculated using Bio-Plex manager software with a five-parameter curve-fitting algorithm applied for standard curve calculation.

\section{Intracellular Cytokine Staining}

For measuring $\mathrm{T}$ cell secreted cytokines, the negatively selected splenic $\mathrm{CD}^{+} \mathrm{T}$ cells (purity was $>93 \%$ ) and splenocyte (for $\mathrm{CD} 8^{+}$ $\mathrm{T}$ cell analysis) from uninfected and $\mathrm{PbA}$-infected mice were cultured in RPMI 1640 complete medium [RPMI 1640 (\# P0416500), PAN-Biotech GmbH, Germany] supplemented with 10\% FBS US origin (\#1302-P100402, PAN-Biotech GmbH, Germany), $50 \mu \mathrm{M}$ 2-ME, $100 \mathrm{U} / \mathrm{ml}$ penicillin and $100 \mu \mathrm{g} / \mathrm{ml}$ streptomycin (\# P4333-100 ml, Sigma-Aldrich, USA) and stimulated by $20 \mathrm{ng} / \mathrm{ml} \mathrm{PMA} / 1 \mu \mathrm{g}$ ionomycin for $5 \mathrm{~h}$ after with Brefeldin A added in the last $2.5 \mathrm{~h}$ of stimulation. Stimulated cells were stained with dead cell discrimination dye for $20 \mathrm{~min}$ on the ice and then washed and stained for surface markers. Surface stained cells were fixed with Fixation/permeabilization buffer of BD Biosciences for $20 \mathrm{~min}$ at room temperature.

\section{Intracellular Transcription Factor Staining}

FoxP3 transcription factor staining kit protocol (eBiosciences, San Diego, CA, USA) was used for intracellular transcription factor staining. In brief, $\mathrm{T}$ cells were stained for desired surface markers after dead cell discrimination and blocking with CD16/32 (2.4 G) antibody. After $20 \mathrm{~min}$ of incubation, the cells were washed twice and then fixed and permeabilized at room temperature for $20 \mathrm{~min}$ as recommended by the manufacturer. The cells were then washed twice with permeabilization buffer and then stained with transcription factor antibody cocktail for 20-30 $\mathrm{min}$ at room temperature.

\section{Statistical Analysis}

Non-parametric Mann-Whitney test was used for comparisons between two groups. One-way ANOVA with Bonferroni's Multiple Comparison Test was used for multiple comparisons having three or more groups. Two-way ANOVA with Bonferroni posttest was used for comparing weight lost. A log-rank (Mantel-Cox) test was used to determine the significance of survival of $\mathrm{PbA}$ infected mice with or without anti-ratIgG2b and anti-ICOS treatment. Graphs depict mean values \pm SEM. $p$-value $<0.05$ $\left.{ }^{\star} p<0.05 ;{ }^{* *} p<0.01 ;{ }^{* *} p<0.001\right)$ was considered significant. All graphs were prepared with Prism 5.0 (GraphPad, La Jolla, CA, USA) software.

\section{RESULTS}

\section{Anti-ICOS Administration Slows $P$. berghei ANKA Growth and Prolonged Mice Survival}

To understand the possible involvement of ICOS in the lethality of blood stage $P b A$ infection, we first established parasite infection in $\mathrm{BALB} / \mathrm{c}$ mice by intravenous injection of $1 \times 10^{4}$ parasitic $\mathrm{RBCs}$. To one group of $\mathrm{PbA}$-infected mice, a single dose of antiICOS was given while to another group, rat-anti-IgG2b antibody was injected. On every alternate day starting from day 3, percent parasitemia was ascertained from Giemsa-stained thin blood smear prepared from tail vein blood. On Day 3, the mean parasitemia in untreated $(0.0875 \pm 0.025 \%)$, anti-ICOS $(0.1 \%)$, and anti-rat IgG2b $(0.1 \%)$ treated mice were found to be similar, indicating that infection in all the groups started equally. On Day 5 of infection, we observed lowered percent parasitemia albeit non-significant in anti-ICOS treated mice $(2.125 \pm 0.478 \%)$ when compared to untreated $(3.62 \pm 0.643 \%)$ and rat IgG2b-treated $(3.5 \pm 0.408 \%)$ mice. Statistically significant lower parasitemia in anti-ICOS treated $(4.16 \pm 0.372, p$-value $<0.001)$ as compared to untreated $\mathrm{PbA}$ group $(10.916 \pm 1.067)$ (Figure 1A) was established on day 7. Lowered parasitemia in anti-ICOS-treated mice suggested that ICOS indeed played a significant role in parasite growth. Further, analyzing for the survival of the mice, anti-ICOS treated mice survived significantly longer than the rat IgG2b treated and rat IgG2b treated mice survived longer than the non-treated one (Figure 1B). Eventually, anti-ICOS treated mice died with hyperparasitemia. Next, we analyzed percent weight loss; a pathological marker in anti-ICOS treated and untreated mice during $\mathrm{PbA}$ infection. On day 5 and day 7 of $\mathrm{PbA}$ infection, significantly reduced percent weight loss was observed in anti-ICOS treated mice as compared to $\mathrm{PbA}$-infected mice (Figure 1C). The above results indicated that ICOS plays a significant role in $\mathrm{PbA}$ parasite growth and pathogenesis. 

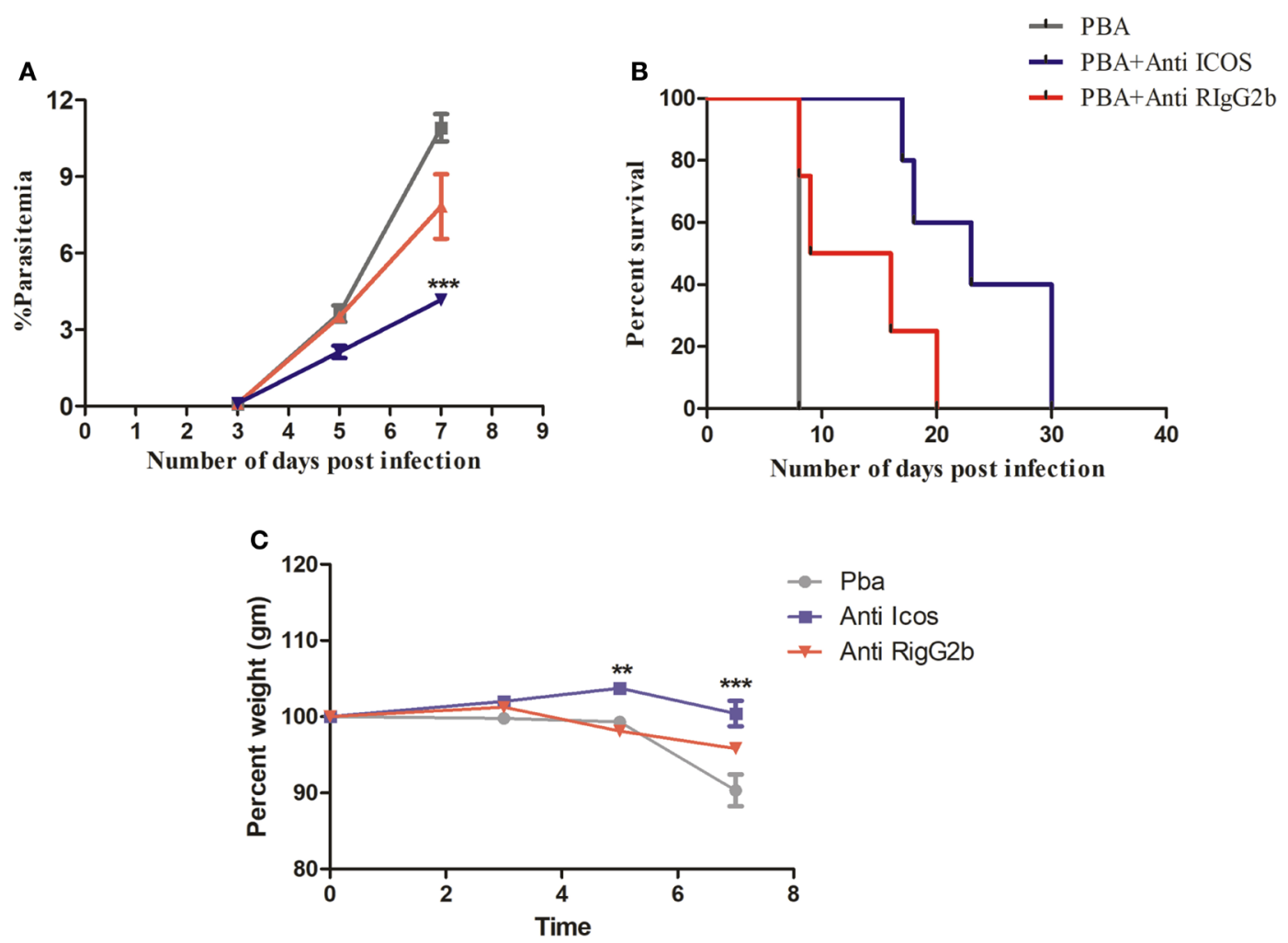

FIGURE 1 | Inducible costimulator (ICOS) positively regulates Plasmodium berghei ANKA parasite growth and pathogenesis. BALB/c mice ( $n=6 /$ group) were infected with i.v. injection of $1 \times 10^{4} \mathrm{P}$. berghei ANKA and on day 1 of infection treated with a single dose of anti-ICOS (200 $\left.\mu \mathrm{g}\right)$ or isotype control (200 $\left.\mu \mathrm{g}\right)$. (A) Percent parasitemia calculated from Geimsa-stained tail vein blood. (B) Percent survival of mice from Plasmodium berghei ANKA infection with anti-ICOS treatment and isotype control. (C) Percent weight loss a marker of immunopathology. Data represent one of the two independent experiments. Bar represent mean \pm SEM. Statistics: Mann-Whitney test, two-way ANOVA with Bonferroni posttest was used for comparing weight loss. Log-rank (Mantel-Cox) test applied for significance of percent survival, $p$-value $<0.05\left({ }^{\star} p<0.05 ;{ }^{\star \star} p<0.01 ;{ }^{\star \star \star} p<0.001\right)$ considered significant.

It is well known that regulation of pro-inflammatory (IFN- $\gamma$, TNF- $\alpha$, IL-6, IL-17) and anti-inflammatory (IL-10, IL-4) cytokines play a pivotal role in malaria parasite growth, protection, and/or pathogenesis (28-32). Moreover, previous studies in blood stage infection of $\mathrm{PbA}$ have determined the crucial role of IFN- $\gamma$ in immunopathology and death. However, during acute non-lethal blood-stage malaria infection, IL-27-mediated IL-10 production from IFN- $\gamma$-producing $\mathrm{CD} 4^{+} \mathrm{T}$ cells has been shown to play an essential role in protection from immune pathology (33). Thus, we scored for plasma cytokine IFN- $\gamma$, IL-4, IL-10, IL-17, IL-6, IL-27, and TNF- $\alpha$ during PbA infection in BALB/c mice with and without anti-ICOS treatment. In plasma samples of PbAinfected mice, significantly higher IFN- $\gamma$ levels were observed as compared to other tested cytokines (Figure $\mathbf{2 A}$ ). The ratio of cytokines in infected to uninfected samples (fold change) also suggested that IFN- $\gamma$ production was higher than other tested cytokines between the groups (Figure 2B). Moreover, significantly higher IFN- $\gamma$ was observed on day 5 and 7 of $\mathrm{PbA}$ infection as compared to day 3 (Figure 2C). Interestingly, significantly reduced plasma IFN- $\gamma$ level was found after anti-ICOS treatment (Figure 2D). Also, non-significant changes in the levels of cytokine IL-10 (Figure 2E), IL-4 (Figure 2F), and no difference in the levels of other tested cytokines were observed (data not shown). Altogether, this suggested the critical involvement of ICOS in malaria parasite growth and lethality might be through IFN- $\gamma$ production.

\section{ICOS Expression During Blood Stage $P$. berghei ANKA Infection}

To investigate the role of ICOS and cells associated with its expression for $\mathrm{PbA}$ lethality, we scored ICOS expression on lymphocytes. On day 3 and day 6 of $P b A$ infection, mice were sacrificed and their spleens analyzed for surface markers to identify ICOS expression on $\mathrm{CD}^{+}, \mathrm{CD}^{+}, \mathrm{NK}, \mathrm{NKT}$, and $\mathrm{B}$ cells by flow cytometry. After gating out doublets and dead cells (Figure 3A), we observed higher ICOS expression on $\mathrm{CD}^{+}$and $\mathrm{CD} 8^{+} \mathrm{T}$ cells (Figure 3B). Minimal ICOS expression was found on B cells, NK cells, and NKT cells in PbA infected and uninfected mice (data not shown) that did not vary with progressive infection. On day 6 of infection, however, we observed an increased percentage of ICOS-positive $\mathrm{CD} 4^{+}$and $\mathrm{CD}^{+} \mathrm{T}$ cells as compared to uninfected mice (Figures 3C-E). A significant increase in mean fluorescent intensity for ICOS on $\mathrm{CD}^{+}$and $\mathrm{CD}^{+} \mathrm{T}$ cells suggested that expression of ICOS at protein level per cell was also higher on day 6 of PbA infection (Figures 3F,G). Anti-ICOS treatment significantly reduced the percentage of ICOS-positive 

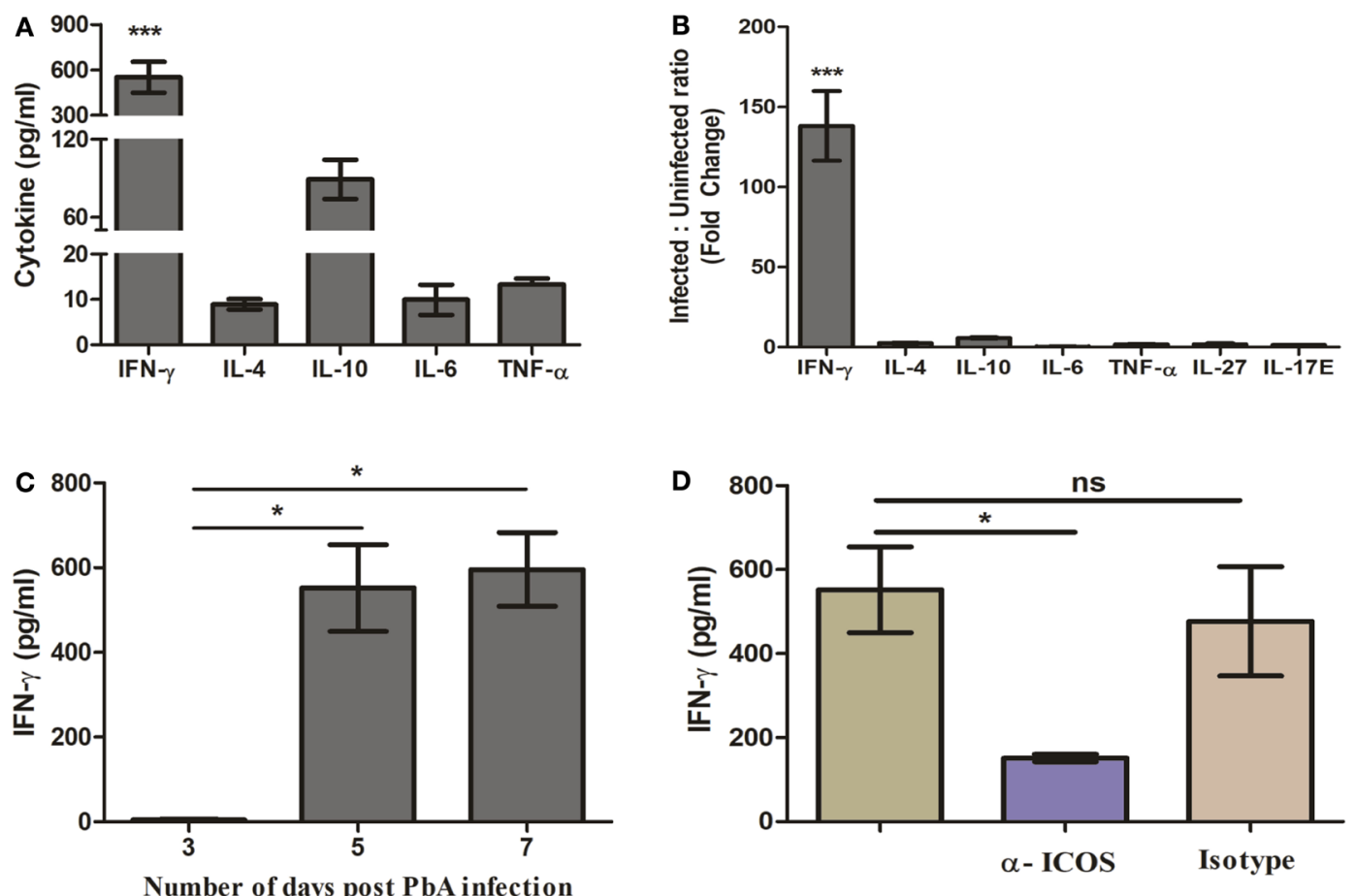

$\mathrm{PbA}$
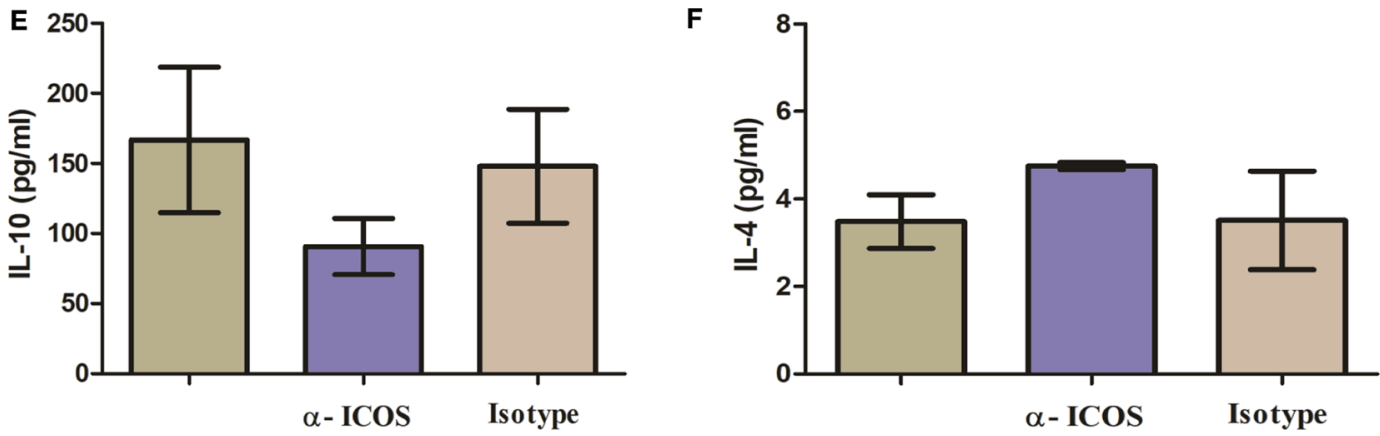

$\mathrm{PbA}$

$\mathrm{PbA}$

FIGURE 2 | Th1 cytokine IFN- $\gamma$ is highly produced during PbA infection. Plasma was collected on indicated days from anti-inducible costimulator (ICOS), anti-ratlgG2b, untreated PbA infected and uninfected (control) mice ( $N=3 /$ group). The collected plasma was analyzed for cytokine IFN- $\gamma$, IL-4, IL-10, IL-6, TNF- $\alpha$, IL-27, and IL-17E with bioplex ELISA. (A) Th1 cytokine IFN- $\gamma$ is significantly increased as compared to Th2 (IL-4), Treg (IL-10), TNF- $\alpha$, and IL-6 in Plasmodium berghei ANKA (PbA)-infected mice. (B) Percent cytokine change as compared to uninfected mice. (C) Kinetics of IFN- $\gamma$ during PbA infection. (D) Reduction in plasma IFN- $\gamma$ production by anti-ICOS treatment. (E) Plasma level of IL-10 (F) plasma level of IL-4. Data represent one of the two independent experiments. Bar represent mean \pm SEM. Statistics: Mann-Whitney test, one-way ANOVA with Bonferroni's Multiple Comparison Test, $p$-value $<0.05$ ( ${ }^{*} p<0.05$; ${ }^{* *} p<0.01$; $\left.{ }^{\star * *} p<0.001\right)$ considered significant.

$\mathrm{CD}^{+}$and $\mathrm{CD} 8^{+} \mathrm{T}$ cells (Figures $\mathbf{3 H}-\mathbf{J}$ ) while ICOS MFI on nondepleted $\mathrm{T}$ cells from anti-ICOS treated mice was significantly lower (Figures 3K,L) than untreated and RatIgG-treated mice. Moreover, we observed significant depletion in percent activated $\left(\mathrm{CD} 44^{\mathrm{hi}} \mathrm{CD} 62 \mathrm{~L}^{\mathrm{lo}}\right)$ as well as total ICOS expressing CD44 ${ }^{\mathrm{hi}} \mathrm{CD} 62 \mathrm{~L}^{\text {lo }}$ $\mathrm{CD}^{+} \mathrm{T}$ cells upon anti-ICOS treatment (Figures $3 \mathrm{M}, \mathbf{N}$ ). Further, we observed non-significant depletion in percent activated $\left(\mathrm{CD} 44^{\mathrm{hi}} \mathrm{CD} 62 \mathrm{~L}^{\mathrm{lo}}\right) \mathrm{CD}^{+} \mathrm{T}$ cells and a significant depletion in ICOS expressing CD $44^{\text {hi }}{ }^{C D} 62 L^{\text {lo }}$ CD ${ }^{+}$T cells (Figures 3O,P). However, anti-Rat IgG2b administration non-significantly reduced ICOS expressing $\mathrm{CD}^{+}$and $\mathrm{CD}^{+} \mathrm{T}$ cells (Figures 3I,K,N,P). Collectively, the above data indicated that $\mathrm{PbA}$ growth and lethality might be associated with ICOS expressing CD $4^{+}$and $\mathrm{CD} 8^{+} \mathrm{T}$ cells.

\section{IFN- $\gamma$-Producing CD4+ T Cells Are Highly ICOS Positive at Protein Level}

Higher ICOS expression on T cells and increased plasma IFN- $\gamma$ production suggested that ICOS expressing T cells may be the source and major producers of IFN- $\gamma$. Thus, to quantify IFN- $\gamma$ 
production by ICOS expressing $\mathrm{CD}^{+} \mathrm{T}$ cells, on day 6 , we negatively isolated $\mathrm{CD}^{+} \mathrm{T}$ cells from uninfected and $\mathrm{PbA}$ infected $\mathrm{BALB} / \mathrm{c}$ mice and stimulated them with PMA/ionomycin. The stimulated cells were analyzed for ICOS and IFN- $\gamma$ co-expression by staining cells with anti-ICOS, anti-IFN- $\gamma$ antibodies after dead cell discrimination and Fc blocking (Figure 4A). As expected, we found a significant increase in the percentage of ICOS ${ }^{+} \mathrm{IFN}-\gamma^{+} \mathrm{CD} 4^{+}$
T cells from $\mathrm{PbA}$-infected mice as compared to uninfected mice (Figure 4B). Increased integrated mean fluorescent intensity for IFN- $\gamma$ depicted that IFN- $\gamma$ production was significantly higher in $\mathrm{CD}^{+} \mathrm{T}$ cell from infected mice than in uninfected mice at the protein level (Figure 4C). We further analyzed ICOS expression on IFN- $\gamma$ positive and IFN- $\gamma$ negative $\mathrm{CD}^{+}{ }^{+} \mathrm{T}$ cells from $\mathrm{PbA}$-infected mice. We found that ICOS expression per cell






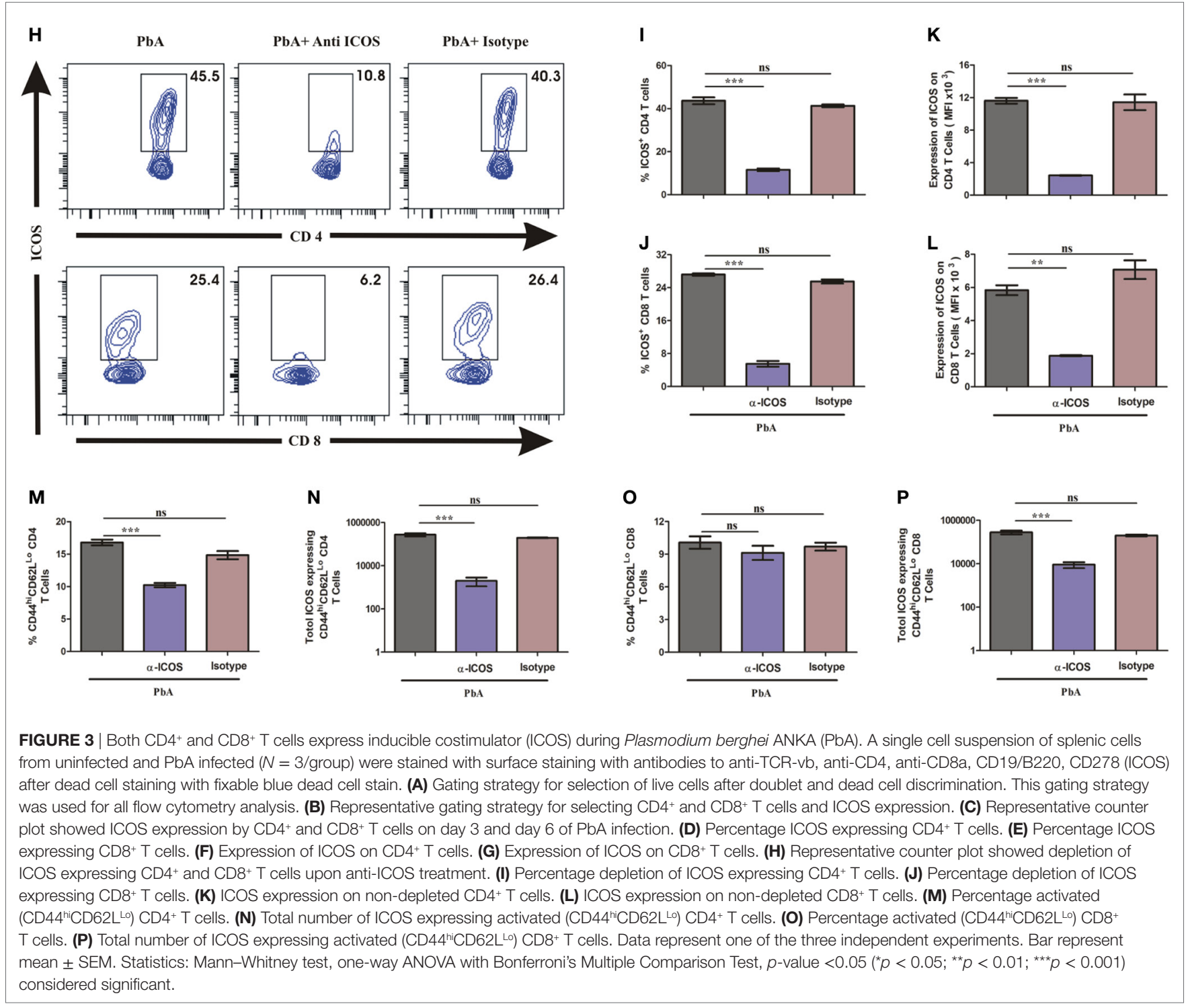

(as scored with mean fluorescent intensity) was significantly higher on IFN $-\gamma^{+}$cells than the negative ones (Figure 4D). Moreover, anti-ICOS treatment significantly reduced percentage as well as total ICOS ${ }^{+} \mathrm{IFN}-\boldsymbol{\gamma}^{+} \mathrm{CD} 4^{+}$T cells (Figures $4 \mathrm{E}, \mathrm{F}$ ). Taken together, our data for $\mathrm{CD}^{+} \mathrm{T}$ cells suggest that ICOS may play a role in IFN- $\gamma$ production based on correlation of ICOS expression and IFN- $\gamma$ production. It also clearly indicated that all IFN- $\gamma$ producing $\mathrm{CD} 4^{+} \mathrm{T}$ cells were ICOS positive but all ICOS-positive $\mathrm{CD} 4^{+} \mathrm{T}$ cells were not IFN- $\gamma$ producers.

\section{ICOS Expressing CD8 ${ }^{+} \mathrm{T}$ Cells Are Higher IFN- $\gamma$ Producers}

To ascertain the role of ICOS in the production of IFN- $\gamma$ by $\mathrm{CD}^{+} \mathrm{T}$ cells during $\mathrm{PbA}$ infection, we stimulated single cell splenocyte with PMA/ionomycin. The stimulated cells were stained with anti-TCR-Vb, anti-CD8a, anti-ICOS, and anti-IFN- $\gamma$ antibodies. After gating TCR- $\mathrm{Vb}$ and $\mathrm{CD}^{+}$, we observed four populations including ICOS ${ }^{+} \mathrm{IFN}-\gamma^{-}, \mathrm{ICOS}^{+} \mathrm{IFN}-\gamma^{+}, \mathrm{ICOS}^{-} \mathrm{IFN}-\gamma^{+}$, and
ICOS - IFN- $\gamma^{-} \mathrm{CD}^{+}$T cells (Figure 4G). We observed that all ICOSexpressing $\mathrm{CD}^{+} \mathrm{T}$ cells were not IFN- $\gamma$ producers and all IFN- $\gamma$ producers were not ICOS expressing (Figure 4G). Additionally, we found a significant increase in percent ICOS ${ }^{+} \mathrm{IFN}-\gamma^{+} \mathrm{CD}^{+}$ $\mathrm{T}$ cells in $\mathrm{PbA}$-infected mice as compared to both the $\mathrm{CD} 8^{+}$ $\mathrm{T}$ cell populations $\left(\mathrm{ICOS}^{-} \mathrm{IFN}-\gamma^{+}, \mathrm{ICOS}^{+} \mathrm{IFN}-\gamma^{+}\right.$) of uninfected mice $(4 \mathrm{H})$. Moreover, in $\mathrm{PbA}$-infected mice, the percentage of ICOS ${ }^{+} \mathrm{IFN}-\gamma^{+} \mathrm{CD}^{+} \mathrm{T}$ cells was significantly higher than the ICOS-IFN- $\gamma^{+}$population (Figure $4 \mathbf{H}$ ). Increased mean fluorescence intensity of IFN- $\gamma$ in $\mathrm{ICOS}^{+} \mathrm{CD}^{+}{ }^{+}$T cells than $\mathrm{ICOS}^{-}$depicted that ICOS expressing $\mathrm{CD}^{+} \mathrm{T}$ cells were higher IFN- $\gamma$ producers (Figure 4I). Moreover, ICOS expression in $\mathrm{PbA}$-infected mice was higher on $\mathrm{ICOS}^{+} \mathrm{IFN}-\gamma^{+} \mathrm{CD}^{+} \mathrm{T}$ cells than ICOS ${ }^{+} \mathrm{IFN}-\gamma^{-}$ $\mathrm{CD}^{+} \mathrm{T}$ cells as determined by the increased mean fluorescent intensity (Figure 4J). In addition, we found anti-ICOS treatment significantly reduced percentage as well as total ICOS ${ }^{+}$IFN- $\gamma^{+}$ $\mathrm{CD}^{+} \mathrm{T}$ cells (Figures 4K,L). Taken together, the above results suggested that during $\mathrm{PbA}$ infection, IFN- $\gamma$ was produced by 
A
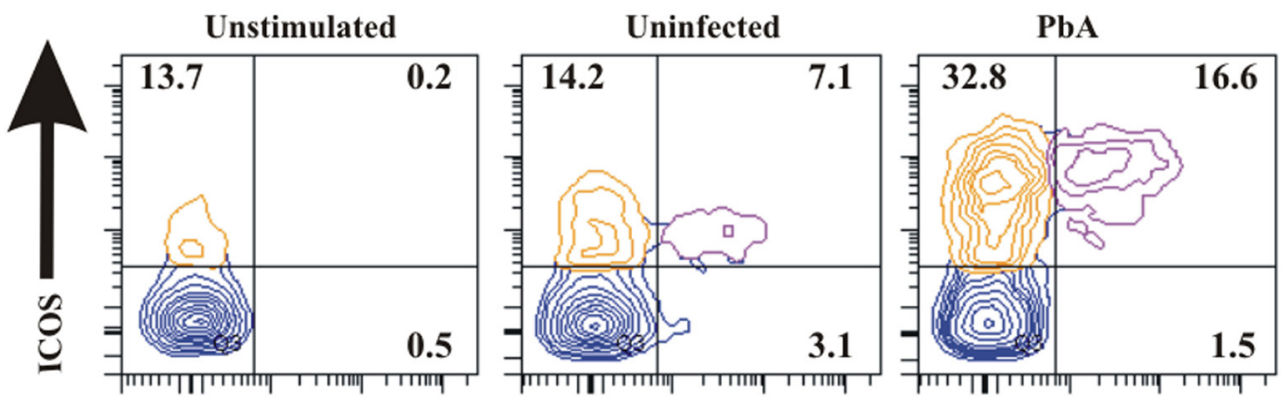

IFN- $\gamma$
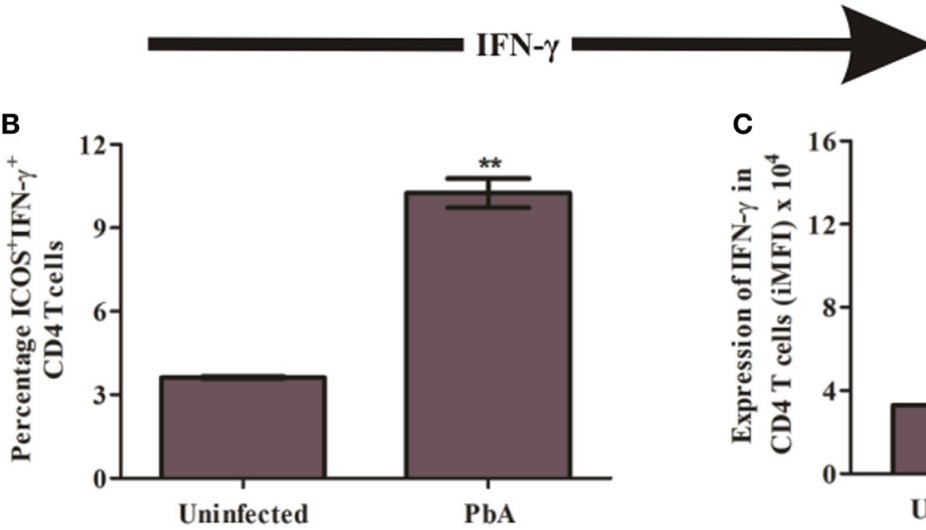

C

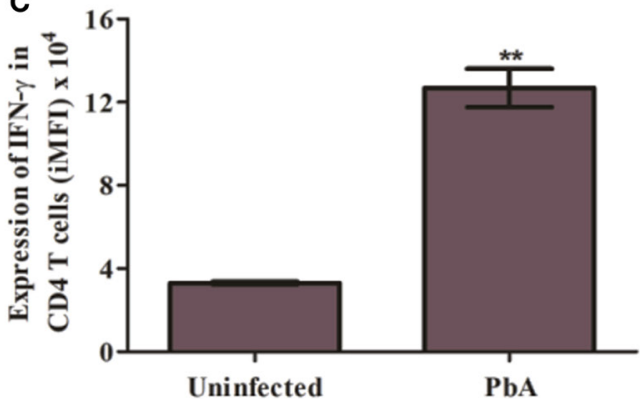

$$
\text { D }
$$
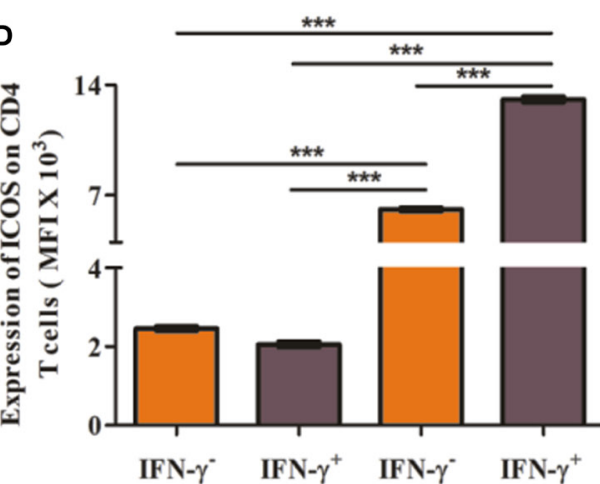

E
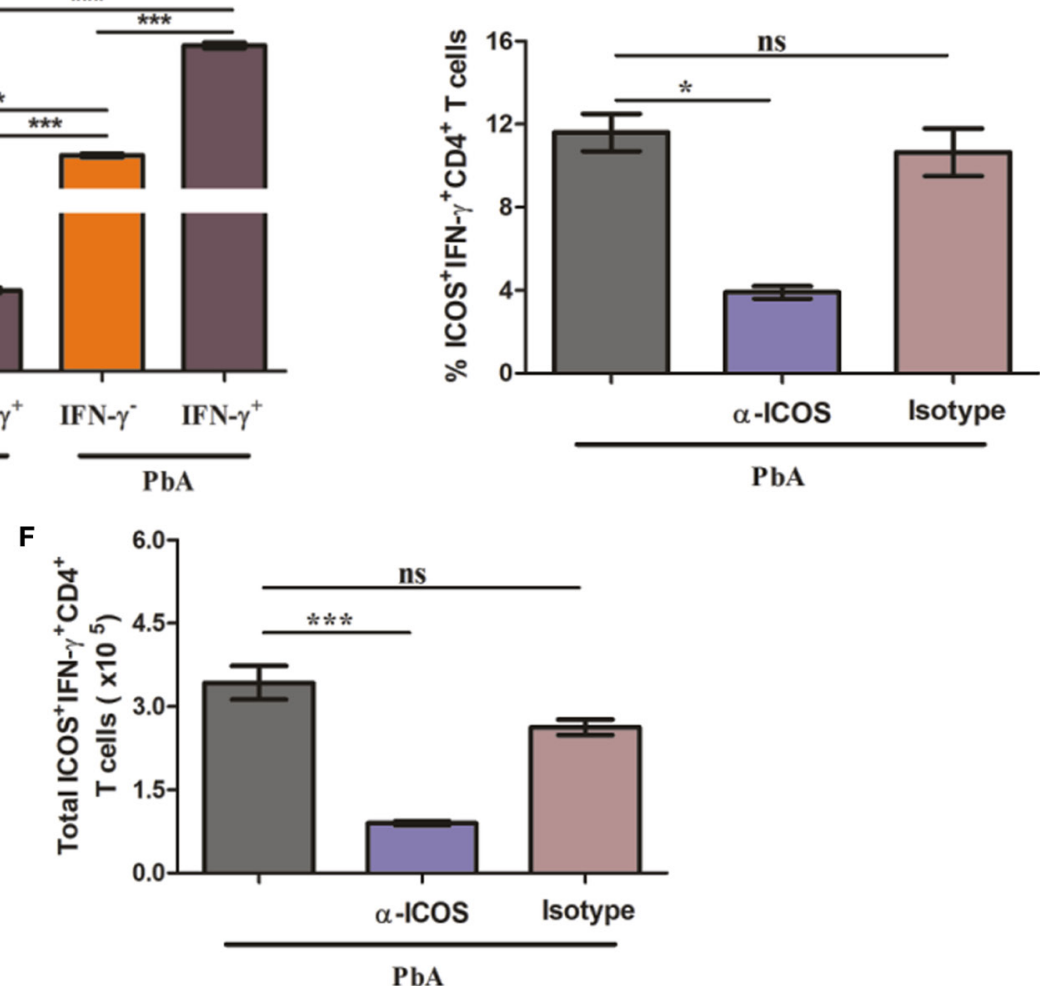

FIGURE 4 | Continued 
G
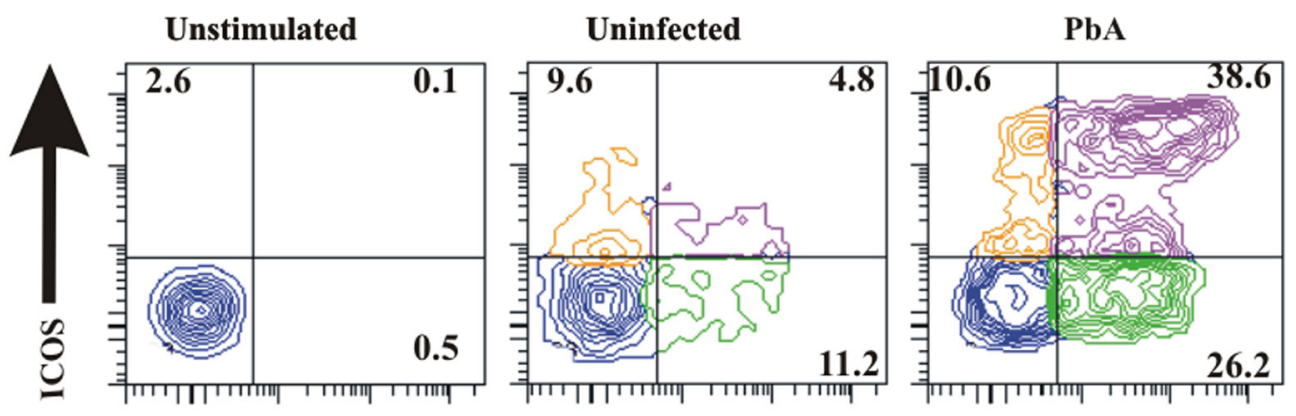

IFN- $\gamma$

H


K

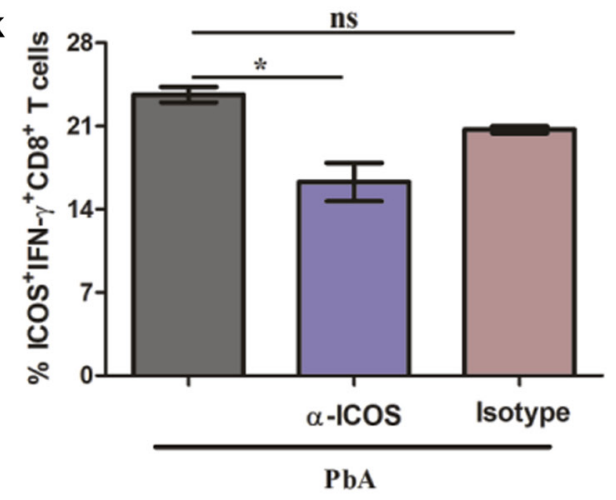



PbA 
FIGURE 4 | Higher inducible costimulator (ICOS) expression on IFN- $\gamma$ producing T cells. Negatively isolated CD4 ${ }^{+} T$ cells and single cell splenocyte from Plasmodium berghei ANKA infected and uninfected mice ( $N=5 /$ group) were stimulated by Phorbol 12-myristate 13-acetate/lonomycin for $5 \mathrm{~h}$ with Brefeldin A at last $2.5 \mathrm{~h}$. Stimulated $\mathrm{CD}^{+} \mathrm{T}$ cells were stained with anti-ICOS and anti-IFN- $\gamma$ after dead cell discriminator staining and Fc blocking. The stimulated single cell splenocytes were stained with anti-TCR-vb, anti-CD8a, anti-ICOS, and IFN- $\gamma$. (A) Representative counter plot show co-expression of ICOS and IFN- $\gamma$ by CD4 $4^{+}$ T cells. (B) Percentage increase in ICOS IFN- $\gamma^{+} \mathrm{CD} 4^{+}$T cells. (C) Increased expression of IFN- $\gamma$ in CD4 ${ }^{+}$T cells. (D) ICOS expression on IFN- $\gamma^{+}$and IFN- $\gamma^{-}$CD4 $4^{+}$ T cells. (E) Anti-ICOS treatment reduced percentage ICOS+IFN- $\gamma^{+}$CD4 $4^{+} T$ cells. (F) Anti-ICOS treatment depleted total number of ICOS ${ }^{+} I F N-\gamma^{+} C D 4^{+} T$ cells after anti-ICOS treatment. (G) Representative counter plot show expression of ICOS and IFN- $\gamma$ in CD8 ${ }^{+} \mathrm{T}$ cells. (H) Percentage IFN- $\gamma$ positive $\mathrm{CD}^{+} \mathrm{T}$ cells in ICOS ${ }^{+}$and ICOS - population. (I) Expression of IFN- $\gamma$ by ICOS ${ }^{+}$and ICOS ${ }^{-} \mathrm{CD}^{+} \mathrm{T}$ cells. (J) ICOS expression on IFN- $\gamma^{+}$and IFN- $\gamma^{-}$CD8 $8^{+}$T cells. (K) Anti-ICOS treatment reduced percentage ICOS IFN- $\gamma^{+}$CD8 ${ }^{+}$T cells. (L) Anti-ICOS treatment depleted total number of ICOS ${ }^{+}$IFN- $\gamma^{+}$CD $8^{+}$T cells. Data represent one of the two independent experiments. Bar represent mean \pm SEM. Statistics: Mann-Whitney test, one-way ANOVA with Bonferroni's multiple comparison test, $p$-value $<0.05$ $\left({ }^{\star} p<0.05 ;{ }^{* \star} p<0.01 ;{ }^{\star \star *} p<0.001\right)$ considered significant.

$\mathrm{ICOS}^{+}$and $\mathrm{ICOS}^{-} \mathrm{CD}^{+} \mathrm{T}$ cells; however, $\mathrm{ICOS}^{+} \mathrm{CD}^{+} \mathrm{T}$ cells were higher producers of IFN- $\gamma$ than the ICOS$^{-}$ones.

\section{T-Bet Expressing CD4 ${ }^{+}$and $\mathrm{CD}^{+}$ T Cells Have Higher ICOS}

The master transcription factor T-bet importantly involved in regulating IFN- $\gamma$ has been shown to play a paradoxical role during blood-stage malaria infection. As an example, in non-lethal blood stage infection, transcription factor T-bet plays a role in parasite growth wherein T-bet knock out mice infected with Plasmodium yoelii yoelii exhibited lower parasitemia (34). Conversely, during $\mathrm{PbA}$ infection, while T-bet regulated parasite burden, it also promoted ECM pathology (11). Moreover, T-bet expression critically depends on ICOS expression and its downstream signaling (35). Therefore, we hypothesized that ICOS expressing $\mathrm{CD} 4^{+}$and $\mathrm{CD} 8^{+}$ $\mathrm{T}$ cells promote $\mathrm{PbA}$ parasite growth through T-bet expression. Thus, we analyzed co-expression of ICOS and T-bet by $\mathrm{CD} 4^{+}$and $\mathrm{CD} 8^{+} \mathrm{T}$ cells during blood stage $\mathrm{PbA}$ infection. To ascertain ICOS and T-bet co-expression, we negatively isolated $\mathrm{CD} 4^{+} \mathrm{T}$ cells and stimulated with PMA/ionomycin for $5 \mathrm{~h}$. The stimulated $\mathrm{CD} 4^{+}$ $\mathrm{T}$ cells were stained with anti-ICOS and anti-T-bet antibody. We observed low (Lo), intermediate (Int), and high (Hi) $\mathrm{ICOS}^{+} \mathrm{T}^{- \text {bet }^{+}}$ and $\mathrm{ICOS}^{+} \mathrm{T}^{-}$bet ${ }^{-} \mathrm{CD}^{+} \mathrm{T}$ cell population (Figure $\mathbf{5 A}$ ) in $\mathrm{PbA}$ infected mice. Percent ICOS ${ }^{+} \mathrm{T}_{- \text {bet }^{+}}(\mathrm{Lo}), \mathrm{ICOS}^{+} \mathrm{T}_{-}$bet $^{+}$(Int) $\mathrm{CD}^{+} \mathrm{T}$ cells were significantly higher than $\mathrm{ICOS}^{+} \mathrm{T}-$ bet $^{+}(\mathrm{Hi})$ in uninfected mice. Whereas in $\mathrm{PbA}$ infected mice, percent $\mathrm{ICOS}^{+} \mathrm{T}-$ bet $^{+}(\mathrm{Hi})$ and $\mathrm{ICOS}^{+} \mathrm{T}-$ bet $^{+}(\mathrm{Int})$ were significantly higher than $\mathrm{ICOS}^{+} \mathrm{T}$-bet ${ }^{+}(\mathrm{Lo})$ of $\mathrm{PbA}$. Percent $\mathrm{ICOS}^{+} \mathrm{T}$-bet ${ }^{+}{ }^{\text {(Hi,Int,Lo) }} \mathrm{CD}^{+}$ $\mathrm{T}$ cells of infected mice was higher than $\mathrm{ICOS}^{+} \mathrm{T}-$ bet $^{+{ }^{+} \mathrm{Hi}, \text { Int,Lo) }}$ of the uninfected (Figure 5B). We observed significantly higher T-bet expression in $\mathrm{CD}^{+} \mathrm{T}$ cells from $\mathrm{PbA}$-infected mice as compared to the uninfected (Figure 5C). Also, we analyzed ICOS expression on T-bet-positive $\mathrm{CD}^{+} \mathrm{T}$ cells from infected and uninfected mice. We observed significantly higher ICOS expression on T-bet ${ }^{(\mathrm{Int}, \mathrm{Hi})}$ positive $\mathrm{CD} 4^{+} \mathrm{T}$ cells of PbA-infected mice as compared to T-bet ${ }^{+}$(Hi,Int,Lo) of uninfected and T-bet (low) of infected mice (Figure 5D). ICOS expression was significantly higher in T-bet ${ }^{+}(\mathrm{Hi})$ than T-bet ${ }^{-} \mathrm{CD} 4^{+} \mathrm{T}$ cells of $\mathrm{PbA}$-infected mice (Figure 5E). Thus, our data suggested that all T-bet expressing $\mathrm{CD} 4^{+} \mathrm{T}$ cells were ICOS positive, but all ICOS-positive $\mathrm{CD} 4^{+}$ $\mathrm{T}$ cells were not expressing T-bet.

Similar to $\mathrm{CD}^{+} \mathrm{T}$ cells, we determined the role of ICOS for T-bet expression in $\mathrm{CD}^{+} \mathrm{T}$ cells during $\mathrm{PbA}$ infection. The splenocytes were stimulated as described earlier and stained with TCR-Vb, CD8a, ICOS, and T-bet antibodies. After gating
TCR-vb and CD8 $8^{+}$, we observed four populations; $\mathrm{ICOS}^{+} \mathrm{T}-\mathrm{bet}^{+}$ ${ }^{(\mathrm{Hi})} \mathrm{ICOS}^{+} \mathrm{T}-\mathrm{bet}^{+}{ }^{(\mathrm{Lo})}$, ICOS ${ }^{+} \mathrm{T}-\mathrm{bet}^{-}{ }^{(\mathrm{Hi})}$, and $\mathrm{ICOS}^{+} \mathrm{T}-$ bet $^{-}{ }^{(\mathrm{Lo})}$ of $\mathrm{CD}^{+} \mathrm{T}$ cells (Figure 5F). A significant increase in percent ICOS $^{+} \mathrm{T}$-bet ${ }^{+(\mathrm{Hi})} \mathrm{CD}^{+} \mathrm{T}$ cells was observed as compared to ICOS $^{+}$T-bet ${ }^{+}$(Lo) of infected mice. Also, it was higher than the uninfected $\left(\mathrm{ICOS}^{+} \mathrm{T}^{-}\right.$bet $\left.^{+}{ }^{+\mathrm{Hi}, \mathrm{Lo})}\right) \mathrm{CD}^{+} \mathrm{T}$ cell population (Figure 5G). Expression of T-bet at protein level per cell was

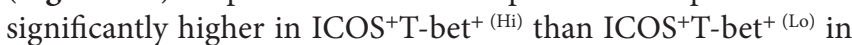
$\mathrm{PbA}$ infected mice and $\mathrm{ICOS}^{+} \mathrm{T}-$ bet $^{+}{ }^{+(\mathrm{Hi})}, \mathrm{ICOS}^{+} \mathrm{T}^{- \text {bet }^{+}}{ }^{(\mathrm{Lo})} \mathrm{CD}^{+}$ $\mathrm{T}$ cells in uninfected mice (Figure 5H). Also, we analyzed ICOS expression on T-bet positive cells from uninfected and $\mathrm{PbA}$ infected mice and found that ICOS expression was higher on ICOS $^{+}$T-bet ${ }^{+}{ }^{(H i)}$ (Figure 5I). Moreover, ICOS expression on T-bet positive $\mathrm{CD}^{+} \mathrm{T}$ cells was higher than T-bet negative cells in infected mice (Figure 5J). Thus, our data suggested that all T-bet expressing $\mathrm{CD} 8^{+} \mathrm{T}$ cells were ICOS positive, but all ICOS positive $\mathrm{CD}^{+} \mathrm{T}$ cells were not expressing T-bet. Taken together, our data indicated that the transcription factor T-bet was expressed by ICOS positive $\mathrm{CD} 4^{+}$as well as $\mathrm{CD} 8^{+} \mathrm{T}$ cells during $\mathrm{PbA}$ infection.

\section{DISCUSSION}

Most symptoms such as fever, anemia, and cerebral manifestations occur during the asexual erythrocytic or blood-stage malaria parasite infection and have been shown to be strongly associated with IFN- $\gamma$ production by various cells. The produced IFN- $\gamma$ is involved in modulation of parasite growth leading to protection as well as pathology $(7,8,29,36-38)$. In experimental allergic encephalomyelitis, IFN- $\gamma$-mediated immunopathology is associated with ICOS expression and its signaling (39). Further, impaired IFN- $\gamma$ production and reduced $\mathrm{CD}^{+}$and $\mathrm{CD} 8^{+} \mathrm{T}$ cell response was observed in ICOS-deficient patients leading to immunodeficiency and autoimmunity $(40,41)$. Moreover, during non-lethal blood-stage malaria infection, ICOS plays an essential role as a regulator of IFN- $\gamma$ production and also in distributing parasite-specific $\mathrm{CD} 4^{+} \mathrm{T}$ cells to both lymphoid and non-lymphoid organs $(20,42)$. Thus, these studies suggested that ICOS could play a role in IFN- $\gamma$ production during infectious and autoimmune diseases (43). ICOS signaling regulate transcription factor T-bet, which is also involved in regulation of malaria parasite growth and pathogenesis $(11,34,35)$. Taking these studies into consideration, we tried to demonstrate the role of ICOS in parasite growth and lethality through T-bet expression and IFN- $\gamma$ production, 
during lethal blood stage of $\mathrm{PbA}$ infection. Thus, in our initial experiment, the depletion of ICOS-expressing cells resulted in significantly lowered parasitemia and prolonged mice survival, suggesting that ICOS positive cells are required for $\mathrm{PbA}$ growth. Lowered parasitemia due to substantial slowing of parasite maturation, was observed during intraerythrocytic P. berghei ANKA infection in $\mathrm{Rag}^{(-)}{ }^{(-)}$(lacks $\mathrm{T}$ and $\mathrm{B}$ cells and mount weakinflammatoryresponse) mice(44). Thus, in ourstudy, we speculate that impaired $\mathrm{T}$ cell response leading to diminished parasitemia might be associated with parasite maturation.

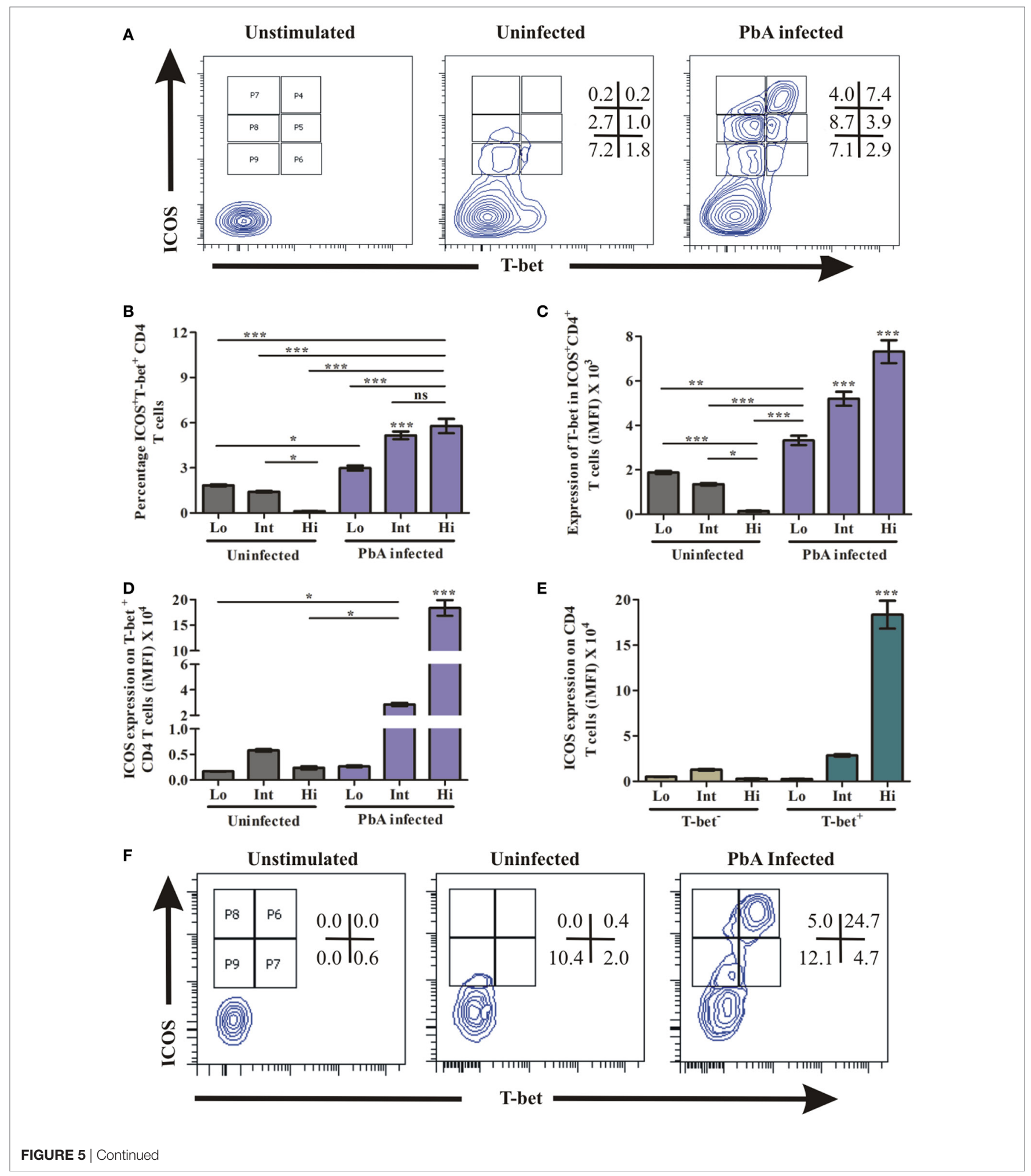


G

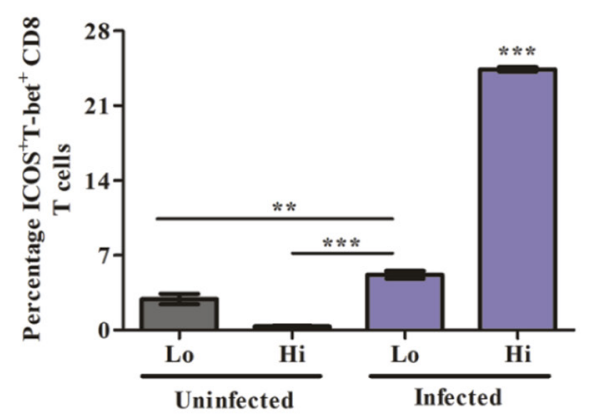

I

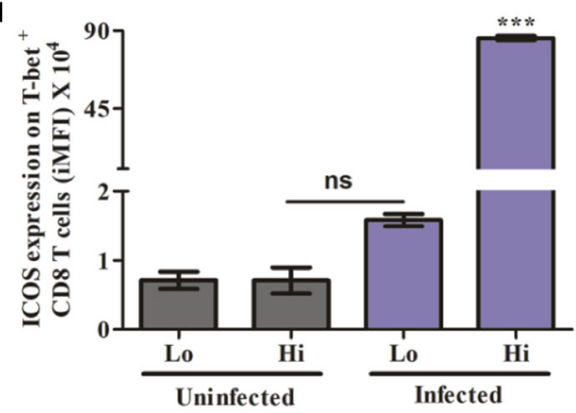

H



$\mathbf{J}$

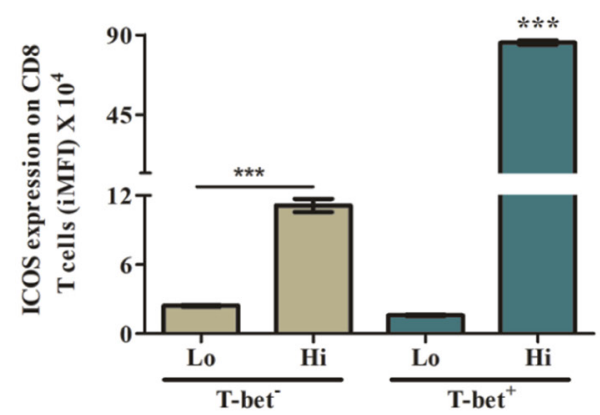

FIGURE 5 | Higher inducible costimulator (ICOS) expression on T-bet-positive T cells. Negatively isolated CD4 ${ }^{+} \mathrm{T}$ cells and single cell splenocyte from Plasmodium berghei ANKA infected and uninfected mice ( $N=3$ /group) were stimulated by Phorbol 12-myristate 13-acetate/ionomycin for 5 h. Stimulated CD4+ $T$ cells were stained with anti-ICOS and anti-T-bet antibodies after dead cell staining and Fc blocking. The stimulated single cell splenocytes were stained with anti-TCR-vb, anti-CD8a, anti-ICOS, and T-bet. (A) Representative counter plot show co-expression of ICOS and T-bet by CD4 ${ }^{+} \mathrm{T}$ cells. (B) Percentage increase in ICOS ${ }^{+} \mathrm{T}$-bet ${ }^{+}$ CD4 ${ }^{+} \mathrm{T}$ cells. (C) Increased expression of T-bet in ICOS ${ }^{+} C D 4^{+} T$ cells. (D) Increased ICOS expression on T-bet positive CD4 ${ }^{+} \mathrm{T}$ cells. (E) ICOS expression on T-bet ${ }^{+}$ and T-bet ${ }^{-}$CD4 ${ }^{+} T$ cells. (F) Representative counter plot show expression of ICOS and T-bet in CD8 ${ }^{+} \mathrm{T}$ cells. (G) Percentage T-bet positive CD8 ${ }^{+} \mathrm{T}$ cells in ICOS ${ }^{+}$ and ICOS population. (H) Expression of T-bet by ICOS ${ }^{+} C D 8^{+} T$ cells. (I) ICOS Expression on T-bet expressing CD8 ${ }^{+} \mathrm{T}$ cells. ( $\left.\mathbf{(}\right)$ ICOS expression on T-bet ${ }^{+}$and T-bet ${ }^{-}$CD8 ${ }^{+} T$ cells. Data represent one of the two independent experiments. Bar represent mean \pm SEM. Statistics: Mann-Whitney test, one-way ANOVA with Bonferroni's multiple comparison test, $p$-value $<0.05\left({ }^{\star} p<0.05 ;{ }^{* \star} p<0.01 ;{ }^{* \star \star} p<0.001\right)$ considered significant.

Further, reduced percent weight loss (a marker of pathology) in anti-ICOS treated mice as compared to untreated suggested that ICOS expressing cells are also involved in $\mathrm{PbA}$ pathology. The role of ICOS in parasite growth and pathology, thus, led us to further characterize its expression during $\mathrm{PbA}$ infection.

During blood-stage malarial infection, helper $\mathrm{CD} 4^{+}$and cytotoxic $\mathrm{CD}^{+} \mathrm{T}$ cells contribute to both protection and pathology (45-48). For activation of both T cells, ICOS expression, and its downstream signaling is critical $(21,40,41,49,50)$. Consistent with this, in our experiment during blood stage $\mathrm{PbA}$ infection, ICOS may be involved in the activation of splenic $\mathrm{CD} 4^{+}$and $\mathrm{CD} 8^{+} \mathrm{T}$ cells as both these cells express significantly higher ICOS. A study involving depletion of these $\mathrm{T}$ cells with antibodies prevented pathology of experimental cerebral malaria (5). Similarly, in this study, upon anti-ICOS administration, depletion of ICOS expressing CD4 ${ }^{+}$ and $\mathrm{CD}^{+} \mathrm{T}$ cells led to lower parasitemia, longer survival, and ameliorated pathology. Thus our study suggested that depletion of ICOS expressing $\mathrm{CD}^{+}$and $\mathrm{CD}^{+}{ }^{+} \mathrm{T}$ cell was sufficient to control parasite growth and lethality as compared to total $\mathrm{T}$ cell depletion.

IFN- $\gamma$ has been known to play a critical role in lethality during $P$. berghei ANKA infection (9) and consistent with these earlier findings, increased plasma IFN- $\gamma$ production in our study may be correlated with its role in $\mathrm{PbA}$ pathogenesis. Lowered parasitemia, reduced IFN- $\gamma$, and increased survival upon anti-ICOS treatment suggest that ICOS plays a role in $\mathrm{PbA}$ growth and lethality through IFN- $\gamma$ production. Further, characterization of $\mathrm{CD}^{+}$and $\mathrm{CD}^{+}$ $\mathrm{T}$ cells for IFN- $\gamma$ production showed that both these cells were indeed IFN- $\gamma$ producers. Moreover, depletion of ICOS-expressing $\mathrm{CD}^{+}$and $\mathrm{CD}^{+} \mathrm{T}$ cells and reduction of plasma IFN- $\gamma$ upon antiICOS treatment suggested that in blood stage of $\mathrm{PbA}$ infection, ICOS expressing $\mathrm{CD}^{+}$and $\mathrm{CD} 8^{+} \mathrm{T}$ cells were the major producers of IFN- $\gamma$. Further, earlier studies also demonstrated the role of ICOS in modulating cytokines of naïve and activated T cells. Moreover, during Mycobacterium tuberculosis, ICOS signaling controlled antigen-specific protective IFN- $\gamma$ production and the produced IFN- $\gamma$, in turn, regulated ICOS expression (24). Similarly, in our study, higher ICOS expression on IFN- $\gamma$ producing $\mathrm{T}$ cells and higher IFN- $\gamma$ production in ICOS expressing T cells suggested that both ICOS and IFN- $\gamma$ could regulate each other.

On similar line master transcription factor T-bet has shown to be involved in malaria parasite growth and pathogenesis. For example, lower parasite burden was observed in T-bet knock out (Tbx $21^{-/-}$) mice than T-bet wild-type mice suggesting that T-bet promotes malaria parasite growth (34). In another study, T-bet regulated $\mathrm{PbA}$ growth but has also been shown to promote the pathogenesis of ECM (11). Interestingly, ICOS expression and its downstream signaling have been shown to be critical for T-bet expression (35). In our study, ICOS expressing CD4 $4^{+}$and $\mathrm{CD} 8^{+}$ 
$\mathrm{T}$ cells, which were involved in $\mathrm{PbA}$ growth has also been shown to co-express T-bet. Our results also demonstrated that ICOS and T-bet might regulate each other's expression as correlated with higher ICOS expression on T-bet positive cells and vice versa.

The malaria parasite has evolved with multiple mechanisms such as changing shapes, motility, metabolic requirement, and immune evasion strategies to survive inside the host (51). In correlation with this, we demonstrated that malaria parasite utilizes ICOS-expressing T cells for their growth through T-bet expression and IFN- $\gamma$ production. Other studies have depicted that altering ICOS signaling leads to modulated T cell response, which in turn is involved in infection clearance, tumor regression, and ameliorated pathology (52-54). Thus, modulation of ICOS expression and its signaling might be helpful in altering parasite growth and lethality, which might be valuable in preventing severe malaria in humans.

\section{ETHICS STATEMENT}

The use of animals and animal procedures were approved by the Institutional Animal Ethics Committee, Institute of Life Sciences, Bhubaneswar, India in accordance with the "Committee for the Purpose of Control and Supervision of Experiments on Animals (CPCSEA)."

\section{AUTHOR CONTRIBUTIONS}

GJ conceived the study and discussed with SD. GJ planned and performed experiments, analyzed data, and drafted manuscript.

\section{REFERENCES}

1. Craig AG, Grau GE, Janse C, Kazura JW, Milner D, Barnwell JW, et al. The role of animal models for research on severe malaria. PLoS Pathog (2012) 8(2):e1002401. doi:10.1371/journal.ppat.1002401

2. de Souza JB, Riley EM. Cerebral malaria: the contribution of studies in animal models to our understanding of immunopathogenesis. Microbes Infect (2002) 4(3):291-300. doi:10.1016/S1286-4579(02)01541-1

3. Langhorne J. The immune response to the blood stages of Plasmodium in animal models. Immunol Lett (1994) 41(2-3):99-102. doi:10.1016/01652478(94)90115-5

4. Suss G, Eichmann K, Kury E, Linke A, Langhorne J. Roles of CD4- and CD8-bearing $\mathrm{T}$ lymphocytes in the immune response to the erythrocytic stages of Plasmodium chabaudi. Infect Immun (1988) 56(12):3081-8.

5. Hermsen C, van de Wiel T, Mommers E, Sauerwein R, Eling W. Depletion of CD4+ or CD8+ T-cells prevents Plasmodium berghei induced cerebral malaria in end-stage disease. Parasitology (1997) 114(Pt 1):7-12. doi:10.1017/ S0031182096008293

6. King T, Lamb T. Interferon-gamma: the Jekyll and Hyde of malaria. PLoS Pathog (2015) 11(10):e1005118. doi:10.1371/journal.ppat.1005118

7. McCall MB, Sauerwein RW. Interferon-gamma - central mediator of protective immune responses against the pre-erythrocytic and blood stage of malaria. J Leukoc Biol (2010) 88(6):1131-43. doi:10.1189/jlb.0310137

8. Shear HL, Srinivasan R, Nolan T, Ng C. Role of IFN-gamma in lethal and nonlethal malaria in susceptible and resistant murine hosts. J Immunol (1989) 143(6):2038-44.

9. Villegas-Mendez A, Greig R, Shaw TN, de Souza JB, Gwyer Findlay E, Stumhofer JS, et al. IFN-gamma-producing CD4+ T cells promote experimental cerebral malaria by modulating CD8+ T cell accumulation within the brain. J Immunol (2012) 189(2):968-79. doi:10.4049/jimmunol.1200688

10. Haque A, Best SE, Ammerdorffer A, Desbarrieres L, de Oca MM, Amante FH, et al. Type I interferons suppress CD4(+) T-cell-dependent parasite
SS, GB, SS, and PB helped to perform components of some of the experiments. SD arranged the grants for the study and edited manuscript. All authors contributed intellectual content and approved it for publication.

\section{ACKNOWLEDGMENTS}

We thank MR4 for providing us with malaria parasite P. berghei ANKA contributed by Mark Weiser M. Hollingdale. We thank Dr. Brian deSouza (London School of Hygiene and Tropical Medicine London) and Dr. Suchitra Mohanty for their critical suggestions. We also thank Dr. Ajay Parida (Director), Dr. B. Ravindran (Former Director), Dr. Durg V. Singh, Dr. Vivek Rai, and Dr. Madhumita Panda from Institute of Life Sciences, Bhubaneswar, for their kind support. We are thankful to the ILS animal facility Staff for supplying mice as required.

\section{FUNDING}

This work was supported in part by core funds from the Institute of Life Sciences and from the Basic Research in Modern Biology Task Force, Department of Biotechnology, Govt. of India (Grant number-BT/PR11259/BRB/10/646/2008 and BT/ PR14425/BRB/10/839/2010). GJ was supported with Senior Research Fellowship of Council of Scientific and Industrial Research (CSIR). control during blood-stage Plasmodium infection. Eur J Immunol (2011) 41(9): 2688-98. doi:10.1002/eji.201141539

11. Oakley MS, Sahu BR, Lotspeich-Cole L, Solanki NR, Majam V, Pham PT, et al. The transcription factor T-bet regulates parasitemia and promotes pathogenesis during Plasmodium berghei ANKA murine malaria. J Immunol (2013) 191(9):4699-708. doi:10.4049/jimmunol.1300396

12. Rummel T, Batchelder J, Flaherty P, LaFleur G, Nanavati P, Burns JM, et al. CD28 costimulation is required for the expression of T-cell-dependent cellmediated immunity against blood-stage Plasmodium chabaudi malaria parasites. Infect Immun (2004) 72(10):5768-74. doi:10.1128/IAI.72.10.5768-5774. 2004

13. Taylor-Robinson AW, Smith EC. Modulation of experimental blood stage malaria through blockade of the B7/CD28 T-cell costimulatory pathway. Immunology (1999) 96(3):498-504. doi:10.1046/j.1365-2567.1999.00718.x

14. Elias RM, Sardinha LR, Bastos KR, Zago CA, da Silva AP, Alvarez JM, et al. Role of $\mathrm{CD} 28$ in polyclonal and specific $\mathrm{T}$ and $\mathrm{B}$ cell responses required for protection against blood stage malaria. J Immunol (2005) 174(2):790-9. doi:10.4049/jimmunol.174.2.790

15. Dong C, Juedes AE, Temann UA, Shresta S, Allison JP, Ruddle NH, et al. ICOS co-stimulatory receptor is essential for T-cell activation and function. Nature (2001) 409(6816):97-101. doi:10.1038/35051100

16. Dong C, Temann UA, Flavell RA. Cutting edge: critical role of inducible costimulator in germinal center reactions. J Immunol (2001) 166(6):3659-62. doi:10.4049/jimmunol.166.6.3659

17. Hutloff A, Dittrich AM, Beier KC, Eljaschewitsch B, Kraft R, Anagnostopoulos I, et al. ICOS is an inducible T-cell co-stimulator structurally and functionally related to CD28. Nature (1999) 397(6716):263-6. doi:10.1038/16717

18. Jogdand GM, Mohanty S, Devadas S. Regulators of Tfh cell differentiation. Front Immunol (2016) 7:520. doi:10.3389/fimmu.2016.00520

19. Kopf M, Coyle AJ, Schmitz N, Barner M, Oxenius A, Gallimore A, et al. Inducible costimulator protein (ICOS) controls $\mathrm{T}$ helper cell subset 
polarization after virus and parasite infection. J Exp Med (2000) 192(1):53-61. doi:10.1084/jem.192.1.53

20. Wikenheiser DJ, Ghosh D, Kennedy B, Stumhofer JS. The costimulatory molecule ICOS regulates host Th1 and follicular Th cell differentiation in response to Plasmodium chabaudi chabaudi AS infection. J Immunol (2016) 196(2):778-91. doi:10.4049/jimmunol.1403206

21. Wallin JJ, Liang L, Bakardjiev A, Sha WC. Enhancement of CD8+ T cell responses by ICOS/B7h costimulation. J Immunol (2001) 167(1):132-9. doi:10.4049/jimmunol.167.1.132

22. Bonhagen K, Liesenfeld O, Stadecker MJ, Hutloff A, Erb K, Coyle AJ, et al. ICOS + Th cells produce distinct cytokines in different mucosal immune responses. Eur J Immunol (2003) 33(2):392-401. doi:10.1002/immu. 200310013

23. de Jong YP, Rietdijk ST, Faubion WA, Abadia-Molina AC, Clarke K, Mizoguchi E, et al. Blocking inducible co-stimulator in the absence of CD28 impairs Th1 and CD25+ regulatory T cells in murine colitis. Int Immunol (2004) 16(2):205-13. doi:10.1093/intimm/dxh019

24. Quiroga MF, Pasquinelli V, Martinez GJ, Jurado JO, Zorrilla LC, Musella RM, et al. Inducible costimulator: a modulator of IFN-gamma production in human tuberculosis. J Immunol (2006) 176(10):5965-74. doi:10.4049/ jimmunol.176.10.5965

25. Liu X, Bai XF, Wen J, Gao JX, Liu J, Lu P, et al. B7H costimulates clonal expansion of, and cognate destruction of tumor cells by, CD8(+) T lymphocytes in vivo. J Exp Med (2001) 194(9):1339-48. doi:10.1084/jem.194.9.1339

26. Vidric M, Bladt AT, Dianzani U, Watts TH. Role for inducible costimulator in control of Salmonella enterica serovar Typhimurium infection in mice. Infect Immun (2006) 74(2):1050-61. doi:10.1128/IAI.74.2.1050-1061.2006

27. Nouailles G, Day TA, Kuhlmann S, Loewe D, Dorhoi A, Gamradt P, et al. Impact of inducible co-stimulatory molecule (ICOS) on T-cell responses and protection against Mycobacterium tuberculosis infection. Eur J Immunol (2011) 41(4):981-91. doi:10.1002/eji.201040608

28. Xu L, Zheng X, Berzins K, Chaudhuri A. Cytokine dysregulation associated with malarial anemia in Plasmodium yoelii infected mice. Am J Transl Res (2013) 5(2):235-45.

29. da Silva HB, de Salles EM, Panatieri RH, Boscardin SB, Rodriguez-Malaga $\mathrm{SM}$, Alvarez JM, et al. IFN-gamma-induced priming maintains long-term strain-transcending immunity against blood-stage Plasmodium chabaudi malaria. J Immunol (2013) 191(10):5160-9. doi:10.4049/jimmunol.1300462

30. Day NP, Hien TT, Schollaardt T, Loc PP, Chuong LV, Chau TT, et al. The prognostic and pathophysiologic role of pro- and antiinflammatory cytokines in severe malaria. J Infect Dis (1999) 180(4):1288-97. doi:10.1086/ 315016

31. Herbert F, Tchitchek N, Bansal D, Jacques J, Pathak S, Becavin C, et al. Evidence of IL-17, IP-10, and IL-10 involvement in multiple-organ dysfunction and IL-17 pathway in acute renal failure associated to Plasmodium falciparum malaria. J Transl Med (2015) 13:369. doi:10.1186/s12967-015-0731-6

32. Lyke KE, Burges R, Cissoko Y, Sangare L, Dao M, Diarra I, et al. Serum levels of the proinflammatory cytokines interleukin-1 beta (IL-1beta), IL-6, IL-8, IL-10, tumor necrosis factor alpha, and IL-12(p70) in Malian children with severe Plasmodium falciparum malaria and matched uncomplicated malaria or healthy controls. Infect Immun (2004) 72(10):5630-7. doi:10.1128/ IAI.72.10.5630-5637.2004

33. Freitas do Rosario AP, Lamb T, Spence P, Stephens R, Lang A, Roers A, et al. IL-27 promotes IL-10 production by effector Th1 CD4+ T cells: a critical mechanism for protection from severe immunopathology during malaria infection. J Immunol (2011) 188(3):1178-90. doi:10.4049/jimmunol.1102755

34. Oakley MS, Sahu BR, Lotspeich-Cole L, Majam V, Thao Pham P, Sengupta Banerjee A, et al. T-bet modulates the antibody response and immune protection during murine malaria. Eur J Immunol (2014) 44(9):2680-91. doi:10.1002/eji.201344437

35. Chen H, Fu T, Suh WK, Tsavachidou D, Wen S, Gao J, et al. CD4 T cells require ICOS-mediated PI3K signaling to increase T-Bet expression in the setting of anti-CTLA-4 therapy. Cancer Immunol Res (2014) 2(2):167-76. doi:10.1158/2326-6066.CIR-13-0155

36. Doe HT, Kimura D, Miyakoda M, Kimura K, Akbari M, Yui K. Expression of PD-1/LAG-3 and cytokine production by CD4(+) T cells during infection with Plasmodium parasites. Microbiol Immunol (2015) 60(2):121-31. doi:10.1111/1348-0421.12354

37. Jagannathan P, Nankya F, Stoyanov C, Eccles-James I, Sikyomu E, Naluwu K, et al. IFNgamma responses to pre-erythrocytic and blood-stage malaria antigens exhibit differential associations with past exposure and subsequent protection. J Infect Dis (2014) 211(12):1987-96. doi:10.1093/infdis/ jiu814
38. Inoue S, Niikura M, Mineo S, Kobayashi F. Roles of IFN-gamma and gammadelta $\mathrm{T}$ cells in protective immunity against blood-stage malaria. Front Immunol (2013) 4:258. doi:10.3389/fimmu.2013.00258

39. Rottman JB, Smith T, Tonra JR, Ganley K, Bloom T, Silva R, et al. The costimulatory molecule ICOS plays an important role in the immunopathogenesis of EAE. Nat Immunol (2001) 2(7):605-11. doi:10.1038/89750

40. Takahashi N, Matsumoto K, Saito H, Nanki T, Miyasaka N, Kobata T, et al. Impaired $\mathrm{CD} 4$ and $\mathrm{CD} 8$ effector function and decreased memory $\mathrm{T}$ cell populations in ICOS-deficient patients. J Immunol (2009) 182(9):5515-27. doi:10.4049/jimmunol.0803256

41. Bossaller L, Burger J, Draeger R, Grimbacher B, Knoth R, Plebani A, et al. ICOS deficiency is associated with a severe reduction of CXCR5+CD4 germinal center Th cells. JImmunol (2006) 177(7):4927-32. doi:10.4049/ jimmunol.177.7.4927

42. Villegas-Mendez A, Shaw TN, Inkson CA, Strangward P, de Souza JB, Couper KN. Parasite-specific CD4+ IFN-gamma+ IL-10+ T cells distribute within both lymphoid and nonlymphoid compartments and are controlled systemically by interleukin-27 and ICOS during bloodstage malaria infection. Infect Immun (2015) 84(1):34-46. doi:10.1128/ IAI.01100-15

43. Wikenheiser DJ, Stumhofer JS. ICOS co-stimulation: friend or foe? Front Immunol (2016) 7:304. doi:10.3389/fimmu.2016.00304

44. Khoury DS, Cromer D, Akter J, Sebina I, Elliott T, Thomas BS, et al. Host-mediated impairment of parasite maturation during blood-stage Plasmodium infection. Proc Natl Acad Sci U S A (2017) 114(29):7701-6. doi:10.1073/pnas.1618939114

45. Chandele A, Mukerjee P, Das G, Ahmed R, Chauhan VS. Phenotypic and functional profiling of malaria-induced CD8 and CD4 T cells during bloodstage infection with Plasmodium yoelii. Immunology (2011) 132(2):273-86. doi:10.1111/j.1365-2567.2010.03363.x

46. Podoba JE, Stevenson MM. CD4+ and CD8+ T lymphocytes both contribute to acquired immunity to blood-stage Plasmodium chabaudi AS. Infect Immun (1991) 59(1):51-8.

47. Good MF, Miller LH. Involvement of T cells in malaria immunity: implications for vaccine development. Vaccine (1989) 7(1):3-9. doi:10.1016/0264410X(89)90002-9

48. Nitcheu J, Bonduelle O, Combadiere C, Tefit M, Seilhean D, Mazier D, et al. Perforin-dependent brain-infiltrating cytotoxic CD8+ T lymphocytes mediate experimental cerebral malaria pathogenesis. JImmunol (2003) 170(4):2221-8. doi:10.4049/jimmunol.170.4.2221

49. Wilson EH, Zaph C, Mohrs M, Welcher A, Siu J, Artis D, et al. B7RP1-ICOS interactions are required for optimal infection-induced expansion of CD4+ Th1 and Th2 responses. J Immunol (2006) 177(4):2365-72. doi:10.4049/jimmunol.177.4.2365

50. Watanabe M, Hara Y, Tanabe K, Toma H, Abe R. A distinct role for ICOSmediated co-stimulatory signaling in $\mathrm{CD} 4+$ and $\mathrm{CD} 8+\mathrm{T}$ cell subsets. Int Immunol (2005) 17(3):269-78. doi:10.1093/intimm/dxh206

51. Renia L, Goh YS. Malaria parasites: the great escape. Front Immunol (2016) 7:463. doi:10.3389/fimmu.2016.00463

52. Zamarin D, Holmgaard RB, Ricca J, Plitt T, Palese P, Sharma P, et al. Intratumoral modulation of the inducible co-stimulator ICOS by recombinant oncolytic virus promotes systemic anti-tumour immunity. Nat Commun (2017) 8:14340. doi:10.1038/ncomms14340

53. Sakthivel P, Gereke M, Breithaupt A, Fuchs D, Gigliotti L, Gruber AD, et al. Attenuation of immune-mediated influenza pneumonia by targeting the inducible co-stimulator (ICOS) molecule on T cells. PLoS One (2014) 9(7):e100970. doi:10.1371/journal.pone.0100970

54. Fan X, Quezada SA, Sepulveda MA, Sharma P, Allison JP. Engagement of the ICOS pathway markedly enhances efficacy of CTLA-4 blockade in cancer immunotherapy. J Exp Med (2014) 211(4):715-25. doi:10.1084/jem.20130590

Conflict of Interest Statement: The authors declare that the research conducted have no commercial or financial involvement that could be considered as potential conflict of interest.

Copyright (๑ 2018 Jogdand, Sengupta, Bhattacharya, Singh, Barik and Devadas. This is an open-access article distributed under the terms of the Creative Commons Attribution License (CC BY). The use, distribution or reproduction in other forums is permitted, provided the original author(s) and the copyright owner are credited and that the original publication in this journal is cited, in accordance with accepted academic practice. No use, distribution or reproduction is permitted which does not comply with these terms. 